\title{
TINGKAT KEBERHASILAN THERABAND THERAPY DALAM MENINGKATKAN RANGE OF MOVEMENT (ROM) PASCA CEDERA PERGELANGAN TANGAN PADA TIM UKM SOFTBALL UNIVERSITAS NEGERI YOGYAKARTA
}

\section{Oleh: Ardi Utomo dan Novita Intan Arofah FIK UNY}

Abstrak

Salah satu jenis cedera yang banyak dialami atlet softball adalah cedera pergelangan tangan yang salah satu gejalanya adalah penurunan range of movement(ROM) pergelangan tangan. Dewasa ini ada beberapa hal yang dapat dilakukan untuk mengatasi cedera pada pergelangan tangan meliputi obat, fisioterapi, terapi manual, dan theraband therapy. Penelitian ini bertujuan mengetahui tingkat keberhasilan theraband therapy dalam meningkatkan range of movement (ROM) pasca cedera pergelangan tangan tim UKM softball UNY.

Penelitian ini merupakan penelitian Pre-Experimental Design dengan desain One-Group Pretest-Postest Design. Populasi dalam penelitian ini adalah pemain softball Universitas Negeri Yogyakarta yang pernah mengikuti berbagai turnamen tingkat daerah, luar daerah dan nasional dengan ROM pergelangan tangan $<80 \%$ normal. Pengambilan sampel dengan teknik purposive sampling dengan jumlah sampel sebanyak 15 orang. Subjek dinilai ROM fleksi, ekstensi, abduksi, dan adduksi sebelum perlakuan (pretest), setelah perlakuan minggu pertama(postest-1), minggu ke-2 (postest-2) dan minggu ke-3 (postest-3) dengan menggunakan jangka dan busur. Analisis data yang digunakan dalam penelitian ini adalah analisis deskriptif, uji efektivitas dan uji beda.

Didapatkan hasil bahwa rata-rata (mean) fleksi sebelum perlakuan theraband therapy (pretest) sebesar $61,20^{\circ}$ dan setalah perlakuan theraband therapy selama 3 minggu naik menjadi $76,07^{\circ}$ atau naik $95,08 \%$ mendekati ROM fleksi normal ( $p$ value $<0,05)$. Selain itu ekstensi pretest sebesar $52,73^{\circ}$ naik menjadi $64,53^{\circ}$ pada postest-3 atau naik mendekati ROM normal sebesar 92, 19\% ( $p$ value $<0,05)$. Abduksi pretest $11,86^{\circ}$ mengalami kenaikan pada postest-3 sebesar $18,13^{\circ}$ atau naik mendekati ROM normal sebesar 90, 67\% ( $p$ value <0,05). Selain itu adduksi pretest $32,53^{\circ}$ mengalami kenaikan pada postest-3 sebesar $43,20^{\circ}$ atau $96,00 \%$ naik mendekati ROM normal $(p$ value $<0,05)$. Dapat disimpulkan bahwa theraband therapy dapat meningkatkan ROM pergelangan tangan pasca cedera.

Kata kunci: Theraband therapy, cedera pergelangan lengan

Dunia olahraga saat ini berkembang dengan pesat, terlihat dari berkembangnya fasilitas alat, gedung latihan dan even-even yang diselenggarakan di berbagai ajang kejuaraan. Dalam hal ini seorang pelatih pasti menginginkan atletnya dapat berprestasi dengan lebih baik, dengan jalan mengoptimalkan latihan. Selain faktor latihan, atlet di tuntut untuk selalu menjaga tubuh supaya tidak terjadi cedera yang dapat menurunkan performa atlet. Apabila sudah 


\section{MEDIKORA Vol. XIV No. 1April 2015}

terjadi cedera atau pasca cedera, perlu dilaksanakan penanganan yang memadai untuk meminimalkan dampaknya pada performa atlet pada saat latihan maupun bertanding.

Salah satu contoh pada olahraga softball, khususnya tim UKM Softball Universitas Negeri Yogyakarta yang sangat rawan akan kembali terjadi cedera pada tubuhnya yang disebabkan oleh faktor intrinsik dan ektrinsik (Susan J. Garrison, 2001: 320). Faktor intrinsik adalah faktor yang timbul dari diri olahragawan, diantaranya kurang pemanasan, beban yang berlebih dan lemahnya kondisi fisik yang dapat menyebabkan atlet mengalami cedera kembali dan nyeri pada bahu, kaki, pinggang, pinggul dan pergelangan tangan, baik saat berlatih maupun bertanding, sedangkan faktor ektrinsik yaitu faktor yang timbul akibat dari luar diri, diantaranya kondisi tempat latihan, alat yang digunakan dan cuaca maupun suhu saat melakukan olahraga. Penyebab yang lain biasanya akibat dari trauma atau benturan langsung ataupun latihan yang berulang-ulang dalam waktu lama (Arif Setiawan, 2011: 95).Faktor cedera yang sering terjadi pada olahraga softball yaitu faktor intrinsik. Salah satu jenis cedera yang banyak dialami atlet softball adalah cedera pergelangan tangan, yang berdampak buruk pada atlet softball karena menimbulkan keterbatasan gerak (penurunan ROM), penurunan kekuatan dan hal tersebut dapat menghambat prestasi seorang atlet.

Dewasa ini ada beberapa hal yang dapat dilakukan untuk mengatasi cedera pada pergelangan tangan meliputi obat, fisioterapi, terapi manual, dan massase. Salah satu alternatif penanganan cedera pergelangan tangan adalah theraband therapy. Theraband therapy merupakan salah satu bentuk terapi latihan berupa karet ( strip elastis ) yang berfungsi untuk pemulihan cedera dan membantu memperkuat fungsi kerja otot (Philip Page and Todd S. Ellenbecker, 2003: 3). Metode ini sering digunakan oleh para fisioterapis untuk memulihkan fungsi kerja otot, ligamen dan tendo yang mengalami penurunan kinerja saat terjadi cedera. Khusus pada theraband therapy belum banyak diteliti. Salah satunya adalah theraband therapy dalam meningkatkan ROM pada pasca cedera pergelangan tangan Unit Kegiatan Mahasiswa Universitas Negeri Yogyakarta (UKM UNY).

\section{Cedera Pergelangan Tangan}

Cedera adalah kelainan yang terjadi pada tubuh yang mengakibatkan timbulnya nyeri, panas, merah, bengkak, dan terjadi penurunan fungsi pada otot, tendon, ligament, persedian ataupun tulang akibat aktivitas gerak yang berlebihan atau kecelakaan (Ali Satia Graha dan Bambang Priyonoadi, 2009:45). Menurut Yustinus Sukarmin (2005: 13), cedera adalah kerusakan atau luka yang dialami atau diderita oleh seseorang. Cedera olahraga adalah segala 


\section{MEDIKORA Vol. XIV No. 1April 2015}

macam cedera yang timbul pada waktu latihan ataupun pada waktu pertandingan (Hardianto Wibowo, 1995: 11), sedangkan menurut Novita Intan Arofah (2010: 3) cedera olahraga adalah gangguan sistem ligament, otot dan rangka tubuh yang disebabkan oleh kegiatan olahraga. G. La. Cava (1995: 145)mengungkapkan bahwa cedera dalam olahraga yaitu rusaknya jaringan lunak atau keras baik otot, tulang, atau persendian yang disebabkan oleh kesalahan teknis, benturan, atau aktivitas yang melebihi batas latihan (overtraining) yang dapat menimbulkan rasa sakit atau nyeri dan akibat dari kelebihan latihan dalam memberikan pembebanan yang terlalu berat (overload) sehingga otot tulang, atau persendian tidak lagi dalam keadaan atau posisi anatomis (dislokasi). Cedera dalam olahraga yang sering dialami oleh atlet ada 2 jenis yaitu truma acuute dan over-use syndrome (Dwi Hatmisari Ambarukmi, 2010: 56).

Cedera yang dialami atlet biasa terjadi karena berbagai faktor dari dalam diri (intrinsik) misalnya dikarenakan salah gerakan.Faktor intrinsik adalah faktor yang unsurunsurnya sudah ada dalam diri atlet.Hal ini meliputi kelemahan jaringan, kelebihan beban, infleksibilitas, kesalahan biomekanik dan kurangnya pengkondisian (Susan J. Garrison 2001; 320).Cedera dapat terjadi kapan saja dalam bentuk aktivitas sehari-hari tanpa disadari maupun disadari salah satunya cedera pergelangan tangan. Pergelangan tangan adalahstruktur kompleks yang sangat rentan terhadap cedera dalam olahraga. Menurut Hardianto Wibowo (1995: 15) cedera olahraga dapat diklasifikasikan sebagai berikut:

1. Cedera ringan atau cedera tingkat pertama, ditandai dengan adanya robekan yang hanya dapat dilihat dengan mikroskop, dengan keluhan minimal dan hanya sedikit saja atau tidak mengganggu performance atlet yang bersangkutan.

2. Cedera sedang atau cedera tingkat kedua, ditandai dengan kerusakan jaringan yang nyata, nyeri, bengkak, berwarna kemerahan dan panas, dengan gangguan fungsi yang nyata dan berpengaruh pada performance atlet yang bersangkutan.

3. Cedera berat atau cedera tingkat ketiga, pada cedera ini terjadi robekan lengkap atau hampir lengkap pada otot, ligamentum, dan fraktur pada tulang, yang memerlukan isrirahat total, pengobatan intensif, bahkan mungkin operasi.

Melihat dari keterangan diatas maka cedera olahraga dapat berdampak pada otot, tendo, ligamen dan tulang. Menurut Hardianto Wibowo (1995: 13) ada dua jenis cedera pada otot, tendo dan ligamentum, yaitu sprain dan strain. Giam dan Teh (1992: 92) berpendapat bahwa sprain adalah cedera pada sendi, dengan terjadi robekan pada ligamentum, hal ini terjadi karena stress berlebihan yang mendadak atau penggunaan yang berlebihan yang berulang- 


\section{MEDIKORA Vol. XIV No. 1April 2015}

ulang dari sendi, sedangkan menurut Sadoso (1990: 11-14) sprain adalah cedera pada ligamentum, cedera ini yang paling sering terjadi pada berbagai cabang olahraga. Strain adalah kerusakan pada suatu bagian otot atau tendo karena penggunaan yang berlebihan ataupun stress yang berlebihan (Giam dan Teh, 1992: 93).

Tanda akut cedera olahraga yang umumnya terjadi adalah tanda respon peradangan tubuh berupa tumor (pembengkakan), kalor (peningkatan suhu), rubor (warna merah), dolor (nyeri) dan funtio laesa (penurunan fungsi) (Novita Intan Arovah, 2010: 4). Paul M. Taylor dan Diane K. Taylor (2002: 31) menyatakan bahwa pada kasus cedera dan peradangan awal akan reda dengan menggunakan RICE, yang dapat dijabarkan sebagai berikut:

1. $\mathrm{R}($ Rest): Diistirahatkan pada bagian yang cedera.

2. I (Ice): Didinginkan selama 15 sampai 30 menit.

3. C (compres): Dibalut tekan pada bagian yang cedera dengan bahan yang elatis, balut tekan diberikan apabila terjadi pendarahan atau pembengkakan.

4. E (Elevation): Ditinggikan atau dinaikkan pada bagian yang cedera.

Pergelangan tangan sering merasa sakit adalah hal umum yang biasa dirasakan oleh seorang atlet, salah satunya carpal tunnel syndrome. Carpal tunnel syndrome merupakan suatu kondisi medis saraf median yang dikompresi di pergelangan tangan. Paul M. Taylor dan Diane K. Taylor (2002: 209) menyatakan bahwa sindrom carpal tunnel terjadi karena adanya iritasi dan tekanan pada saraf median yang terletak di bawah transverse carpal ligament.Tidak hanya cedera carpal tunel syndrome yang dapat dialami masih ada beberapa macam jenis cedera yang dapat mengenai dan menurunkan prestasi seorang atlet antara lain adalah tendonitis, athritis, ganglion, sprain strain dan fractures.

\section{Range Of Movement (ROM)}

Range of movement (ROM) merupakan luas gerak yang dapat dilakukan oleh sendi pada salah satu dari potongan tubuh (sagital, transversal, dan frontal). ROM memiliki pengertian lain yaitu latihan gerakan sendi yang memungkinkan terjadinya kontraksi dan pergerakan otot, dimana posisi pasien menggerakan masing-masing persendiannya sesuai dengan gerakan normal baik secara aktif maupun pasif. Latihan range of motion (ROM) yaitu latihan yang dilakukan untuk mempertahankan atau memperbaiki suatu tingkat kesempurnaan kemampuan menggerakan sendi secara normal dan lengkap untuk meningkatkan massa otot dan tonus otot (Potter \& Perry, 2005: 125).

Havid Maimurahman dan Cemy Nur Fitria (2012:2) mengungkapkan bahwa mengetahui ROM seseorang mempunyai manfaat tersendiri yaitu dapat digunakan, (1) menentukan nilai 


\section{MEDIKORA Vol. XIV No. 1April 2015}

kemampuan sendi tulang dan otot dalam melakukan gerakan (2) mengkaji tulang, sendi, dan otot (3) mencegah terjadinya kekakuan pada persendian (4) memperlancar sirkulasi darah (5) memperbaiki tonus otot (6) meningkatkan mobilisasi sendi (7) memperbaiki toleransi otot untuk latihan. ROM sendiri dibagi menjadi dua jenis yaitu: ROM aktif dan ROM pasif, (1) ROM aktif yaitu penggunaan kekuatan atau energi sendiri untuk melakukan gerakan, dan (2) ROM pasif adalah energi yang dikeluarkan untuk latihan berasal dari orang lain (terapis) atau bantuan alat.

Dijelaskan oleh Basmajian John V. (1980: 89), bahwa Range Of Movement pada sendi pergelangan tangan yaitu sebagai berikut:

Tabel 1.Range Of Movement Sendi Pergelangan Tangan

\begin{tabular}{|c|c|c|}
\hline Joint & Motion & Degrees of Motion \\
\hline \multirow{4}{*}{ Wrist } & Flexion & $80^{\circ}$ \\
\cline { 2 - 3 } & Extension & $70^{\circ}$ \\
\cline { 2 - 3 } & Abduction & $20^{\circ}$ \\
\cline { 2 - 3 } & Adduction & $45^{\circ}$ \\
\hline
\end{tabular}

Latihan range of motion (ROM) adalah latihan yang dilakukan untuk mempertahankan atau memperbaiki tingkat kesempurnaan kemampuan menggerakan persendian secara normal dan lengkap untuk meningkatkan massa otot dan tonus otot dan sebagai dasar untuk menetapkan adanya kelainan ataupun untuk menyatakan batas gerakan sendi yang abnormal (Potter \& Perry, 2005: 125). Pada dasarnya mobilitas sendi sangat penting untuk memaksimalkan ruang gerak sendi, meningkatnya kinerja otot, mengurangi resiko cedera dan memperbaiki nutrisi kartilago. Latihan ROM (fleksibilitas) yang dilakukan pada latihan fisik dapat meningkatkan panjang dan elastisitas otot dan jaringan sekitar sendi.Untuk pasien pasca cedera tangan, latihan fleksibilitas ditujukan untuk mengurangi kekakuan, meningkatkan mobilitas sendi, dan mencegah kontraktur jaringan lunak.Latihan fleksibilitas sering dilakukan selama periode pemanasan atau tergabung dalam latihan ketahanan atau aktivitas aerobic (Lee dkk, 2005: 11).

Latihan fleksibilitas dapat dimulai dari latihan peregangan tiap kelompok otot, setidaknya tiga kali seminggu.Apabila sudah terbiasa, latihan ditingkatkan repitisinya perkelompok secara bertahap.Latihan harus melibatkan kelompok otot dan tendon utama pada ekstremitas atas dan bawah (American society geriatrics, 2001: 815). 


\section{MEDIKORA Vol. XIV No. 1April 2015}

\section{Theraband Therapy}

Theraband therapy merupakan salah satu bentuk terapi latihan berupa karet yang berfungsi untuk pemulihan cedera dan membantu memperkuat fungsi kerja otot, theraband adalah kekuatan karet tipis atau tabung yang digunakan sebagai media penyembuhan yang berfungsi untuk merehabilitasi cedera, meningkatkan kekuatan, fungsional, dan mobilitas sendi. Metode ini sering digunakan oleh para fisioterapis untuk pemulihan cedera pada pergelangan tangan. Theraband memiliki ukuran meliputi tipis, sedang, dan tebal sesuai dengan kebutuhan yang digunakan.

Theraband mempunyai warna kode band yang berbeda-beda sesuai tingkatan dan ketebalan, warna kode band tersebut adalah Warna Tan, Kuning, Merah, Hijau, Biru, Hitam, Silver, dan Gold. Theraband therapy banyak digunakan oleh terapis untuk membantu pemulihan pada pasien yang mengalami cedera seperti halnya pada penderita cedera pergelangan tangan.Menerapkan proses latihan kepada seorang harus memperhatikan kebutuhan klien atau pasien, karena pada setiap pasien yang mengalami cedera memiliki karakteristik yang berbeda-beda. Pada dasarnya program thraband therapy terdiri atas latihan peregangan dan latihan penguatan.

\section{METODE PENELITIAN}

Penelitian ini merupakan penelitian Pre-Experimental Design dengan desain satu kelompok dengan tes awal dan tes akhir (One-Group Pretest-Postest Design) (Sugiyono, 2010: 108). Pada penelitian ini kelompok diukur sebelum dan sesudah mendapat perlakuan theraband therapy. Dalam penelitian ini subyek diberikan tes awal, yaitu pengukuran range of movement (ROM) pada sendi pergelangan tangan pada aspek gerakan fleksi, ekstensi, adduksi, dan abduksi. Kelompok dalam penelitian ini merupakan kelompok yang mengalami pemulihan pasca cedera pergelangan tangan.

Variabel dalam penelitian ini adalah theraband therapy dan Range of Movement (ROM) yang secara operasional variabel tersebut dapat didefinisikan sebagai berikut:

a. Theraband therapy adalah terapi dengan menggunakan kekuatan karet tipis atau tabung yang digunakan sebagai media penyembuhan yang berfungsi untuk merehabilitasi cedera, meningkatkan kekuatan, fungsional, dan mobilitas sendi.

b. Range of movement (ROM) merupakan luas gerak yang dapat dilakukan oleh sendi pergelangan yang dalam hal meliputi gerak fleksi, ekstensi, abduksi, adduksi dengan menggunakan jangka dan busur. 


\section{MEDIKORA Vol. XIV No. 1April 2015}

Populasi dalam penelitian ini adalah pemain softball Universitas Negeri Yogyakarta yang pernah mengikuti berbagai turnamen tingkat daerah, luar daerah dan nasional berjumlah 60 orang. Teknik sampling yang digunakan adalah purposive sampling yaitu teknik sampling yang penentuan sampelnya berdasarkan pertimbangan (Riduwan, 2009: 20). Kriteria yang digunakan yaitu pemain yang mengalami pemulihan pasca cedera pergelangan tangan saat latihan dengan melakukan theraband therapy. Kriteria dengan ROM terukur kurang dari $80 \%$ normal. Nilai normal ROM sebagai berikut: Fleksi: $80^{\circ}$, Ektensi: $70^{\circ}$, Abduksi: $20^{\circ}$, dan Adduksi: $45^{\circ}$. Jumlah pemain yang memenuhi kriteria sampel adalah sebanyak 15 orang, dengan pemberian perlakuan theraband therapy.

Instrumen yang digunakan dalam penelitian ini adalah alat pengukur berupa jangka dan busur untuk mengukur derajat sudut pergerakan sendi (ROM) pergelangan tangan. Data yang dikumpulkan dalam penelitian ini adalah data yang diperoleh dengan menggunakan tes dan pengukuran dari populasi tim softball UNY. Cara pelaksanaan pengumpulan data ini ada dua macam yaitu sebelum diberi perlakuan, dites awal dan sesudah diberikan perlakuan dites akhir. Kedua tes tersebut dilakukan dengan cara mengukur luas gerak (ROM) pergelangan tangan dengan menggunakan jangka kemudian ditentukan besar derajat tersebut dengan busur (Basmajian John V., 1980: 95-96). Dalam penelitian ini analisis deskritif yaitu digunakan untuk mengetahui nilai minimum, nilai maksimum, mean, median, modus, dan standar deviasi.

Data yang diperoleh dari hasil pengukuran dianalisis dengan menggunakan uji (beda) parametrik. Uji-t menghasilkan nilai t hitung dan nilai probabilitas (p) yang dapat digunakan untuk membuktikan hipotesis ada atau tidak adanya pengaruh secara signifikan. Cara menentukan signifikan tidaknya adalah jika nilai $\mathrm{p}<0,05$ maka ada perbedaan signifikan, selanjutnya jika $\mathrm{p}>0,05$ maka tidak ada perbedaan signifikan. Data dianalisis menggunakan taraf kepercayaan sebesar $95 \%$ dengan menggunakan software analisis SPSS 13.00.

\section{HASIL PENELITIAN}

Hasil analisis deskriptif data pengamatan fleksi dapat dilihat pada tabel berikut ini:

Tabel 4. Hasil Analisis Deskriptif Data Fleksi

\begin{tabular}{|l|c|c|c|c|c|c|}
\hline \multicolumn{1}{|c|}{ ROM } & Min & Max & Mean & Median & Modus & Std. Dev \\
\hline Pretest & 54,00 & 66,00 & 61,20 & 61,00 & 61,00 & 3,05 \\
\hline Posttest 1 & 59,00 & 70,00 & 64,67 & 65,00 & 64,00 & 2,85 \\
\hline Posttest 2 & 66,00 & 74,00 & 70,53 & 71,00 & 69,00 & 2,36 \\
\hline Posttest 3 & 73,00 & 79,00 & 76,07 & 76,00 & 75,00 & 1,79 \\
\hline
\end{tabular}


Efektivitas diperhitungkan dengan membandingkan antara ROM terukur dengan ROM keadaan normal yang dalam hal ini fleksi $80^{\circ}$. Hasil perhitungan tingkat efektivitas keberhasilan theraband pasca cedera pergelangan tangan pada UKM Softball UNY yang diamati berdasarkan ROM pada pengukuran fleksi pada saat pretest sebesar 76,50\%, pada pengamatan posttest 1 naik menjadi 80,83. Efektivitas pada posttest 2 sebesar $88,17 \%$ dan pada saat posttest 3 naik menjadi 95,08\%.

Berdasarkan hasil analisis anova diperoleh nilai $\mathrm{F}$ hitung sebesar 98,417 dengan nilai signifikansi sebesar 0,000. Oleh karena nilai signifikansi sebesar 0,000 lebih kecil dari $0,05(p<0,05)$, maka dapat disimpulkan ada perbedaan yang signifikan hasil kemampuan fleksi pada saat pretest, posttest 1 , posttest 2 dan posttest 3. Dilihat dari nilai rerata diketahui hasil posttest 3 menunjukkan angka tertinggi yaitu 76,07 dapat diartikan hasil posttest 3 merupakan hasil terbaik dari perlakuan yang diberikan. Hasil analisis deskriptif data pengamatan ekstensi dapat dilihat pada tabel berikut ini.

Tabel 5. Hasil Analisis Deskriptif Data Ekstensi

\begin{tabular}{|l|c|c|c|c|c|c|}
\hline \multicolumn{1}{|c|}{ ROM } & Min & Max & Mean & Median & Modus & Std. Dev \\
\hline Pretest & 48,00 & 58,00 & 52,73 & 53,00 & 51,00 & 2,71 \\
\hline Posttest 1 & 52,00 & 61,00 & 55,87 & 56,00 & 56,00 & 2,58 \\
\hline Posttest 2 & 52,00 & 64,00 & 58,20 & 58,00 & 56,00 & 3,23 \\
\hline Posttest 3 & 60,00 & 69,00 & 64,53 & 64,00 & 64,00 & 2,26 \\
\hline
\end{tabular}

Efektivitas diperhitungkan dengan membandingkan antara ROM terukur dengan ROM keadaan normal yang dalam hal ini ekstensi $70^{\circ}$. Hasil perhitungan tingkat efektivitas keberhasilan theraband pasca cedera pergelangan tangan pada UKM Softball UNY yang diamati berdasarkan ROM data ekstensi diketahui efektivitas pada pengukuran ekstensi pada saat pretest sebesar 75,33\%, pada pengamatan posttest 1 naik menjadi 79,81\%. Efektivitas pada posttest 2 sebesar $83,14 \%$ dan pada saat posttest 3 naik menjadi $92,19 \%$.

Hasil uji anova pada data posttest untuk membuktikan hipotesis diperoleh nilai $\mathrm{F}$ hitung sebesar 50,561 dengan nilai signifikansi sebesar 0,000. Oleh karenanilai signifikansi sebesar 0,000 lebih kecil dari $0,05(p<0,05)$, maka dapat disimpulkan ada perbedaan yang signifikan hasil kemampuan ekstensi pada saat pretest, posttest 1 , posttest 2 dan posttest 3. Dilihat dari nilai rerata diketahui hasil posttest 2 menunjukkan angka tertinggi yaitu 58,20 dapat diartikan hasil posttest 2 merupakan hasil terbaik dari perlakuan yang 
diberikan.

Hasil analisis deskriptif data pengamatan abduksi dapat dilihat pada tabel berikut ini.

Tabel 6. Hasil Analisis Deskriptif Data Abduksi

\begin{tabular}{|l|c|c|c|c|c|c|}
\hline \multicolumn{1}{|c|}{ ROM } & Min & Max & Mean & Median & Modus & Std. Dev \\
\hline Pretest & 8,00 & 16,00 & 11,86 & 12,00 & 11,00 & 2,13 \\
\hline Posttest 1 & 10,00 & 17,00 & 14,00 & 14,00 & 13,00 & 1,92 \\
\hline Posttest 2 & 13,00 & 19,00 & 16,40 & 16,00 & 16,00 & 1,76 \\
\hline Posttest 3 & 16,00 & 19,00 & 18,13 & 18,00 & 18,00 & 0,91 \\
\hline
\end{tabular}

Efektivitas diperhitungkan dengan membandingkan antara ROM terukur dengan ROM keadaan normal yang dalam hal ini abduksi $20^{\circ}$. Hasil perhitungan tingkat efektivitas keberhasilan theraband pasca cedera pergelangan tangan pada UKM Softball UNY yang diamati berdasarkan ROM data abduksi diketahui efektivitas pada pengukuran abduksi pada saat pretest sebesar 59,33\%, pada pengamatan posttest 1 naik menjadi 70,00 \%. Efektivitas pada posttest 2 sebesar $82,00 \%$ dan pada saat posttest 3 naik menjadi 90,67\%.

Hasil uji anova pada data posttest untuk membuktikan hipotesis penelitian diperoleh nilai $\mathrm{F}$ hitung sebesar 36,919 dengan nilai signifikansi sebesar 0,000. Oleh karenanilai signifikansi sebesar 0,000 lebih kecil dari $0,05 \quad(p<0,05)$, maka dapat disimpulkan ada perbedaan yang signifikan hasil kemampuan abduksi pada saat pretest, posttest 1, posttest 2 dan posttest 3. Dilihat dari nilai rerata diketahui hasil posttest 3 menunjukkan angka tertinggi yaitu 18,13 dapat diartikan hasil posttest 3 merupakan hasil terbaik dari perlakuan yang diberikan.

Hasil analisis deskriptif data pengamatan adbduksi dapat dilihat pada tabel berikut ini.

\section{Tabel 22. Hasil Analisis Deskriptif Data Adduksi}

\begin{tabular}{|l|c|c|c|c|c|c|}
\hline \multicolumn{1}{|c|}{ ROM } & Min & Max & Mean & Median & Modus & Std. Dev \\
\hline Pretest & 29,00 & 36,00 & 32,53 & 33,00 & 31,00 & 1,92 \\
\hline Posttest 1 & 32,00 & 38,00 & 34,86 & 35,00 & 36,00 & 1,68 \\
\hline Posttest 2 & 37,00 & 41,00 & 39,00 & 39,00 & 37,00 & 1,46 \\
\hline Posttest 3 & 42,00 & 44,00 & 43,20 & 43,00 & 43,00 & 0,67 \\
\hline
\end{tabular}

Efektivitas diperhitungkan dengan membandingkan antara ROM terukur dengan ROM keadaan normal yang dalam hal ini adduksi $45^{\circ}$. Hasil perhitungan tingkat efektivitas keberhasilan theraband pasca cedera pergelangan tangan pada UKM Softball UNY yang diamati berdasarkan ROM data adduksi diketahui efektivitas pada pengukuran adduksi pada saat pretest sebesar 72,30\%, pada pengamatan posttest 1 naik menjadi 77,48 \%. Efektivitas 


\section{MEDIKORA Vol. XIV No. 1April 2015}

pada posttest 2 sebesar $86,67 \%$ dan pada saat posttest 3 naik menjadi 96,00\%.

Hasil uji anova pada data posttest untuk membuktikan hipotesis penelitian diperoleh nilai $\mathrm{F}$ hitung sebesar 145,187 dengan nilai signifikansi sebesar 0,000. Oleh karenanilai signifikansi sebesar 0,000 lebih kecil dari $0,05(p<0,05)$, maka dapat disimpulkan ada perbedaan yang signifikan hasil kemampuan adduksi pada saat pretest, posttest 1 , posttest 2 dan posttest 3. Dilihat dari nilai rerata diketahui hasil posttest 3 menunjukkan angka tertinggi yaitu 43,20 dapat diartikan hasil posttest 3 merupakan hasil terbaik dari perlakuan yang diberikan.

\section{PEMBAHASAN}

Hasil analisis data penelitian membuktikan theraband therapy yang diberikan pada Tim UKM Softball UNY mempunyai tingkat keberhasilan yang signifikan dalam menangani pemulihan pasca cedera pergelangan tangan. Dibuktikan dengan hasil analisis uji t pada pengamatan ROM meliputi fleksi, ekstensi, abduksi dan adduksi secara statistik diperoleh hasil yang signifikan $(p<0,05)$. Terdapat peningkatan yang signifikan kemampuan ROM pada pengamatan pretest ke posttest I, posttest I ke posttest 2, posttest 2 ke posttest 3 dan pretest ke posttest 3. Hasil ini menunjukkan bahwa kemampuan ROM meliputi fleksi, ekstensi, abduksi dan adduksi mengalami peningkatan setelah diberikan theraband therapy.

Cedera pergelangan tangan merupakan jenis cedera yang banyak dialami oleh pemain Softball. Cedera pergelangan tangan dapat disebabkan karena beban pemukul Softball, pukulan yang tidak tepat dan dapat juga disebabkan karena over used. Cedera pergelangan tangan dapat menyebabkan gangguan aktivitas karena tangan merupakan salah satu anggota tubuh yang paling banyak digunakan dalam aktivitas sehari-hari. Cedera pergelangan tangan membutuhkan penanganan menggunakan teknik yang tepat agar mampu menyembuhkan cedera secara maksimal.

Hasil penelitian ini menunjukkan theraband therapy mempunyai tingkat keberhasilan yang signifikan dalam menangani pemulihan pasca cedera pergelangan tangan.Hal ini dapat dijelaskan karena theraband therapy dapat memulihkan fungsi kerja otot, ligamen dan tendo yang mengalami penurunan kinerja saat terjadi cedera.Saat mengalami cedera terjadi penurunan fungsi seperti pada fungsi kerja otot, ligamen dan tendo. Pemberian theraband therapy dengan menggunakan teknik dan dosis yang tepat mampu memulihkan fungsi kerja otot sehingga dapat membantu memulihkan cedera.Didukung dengan pendapat dari (Novita Intan Arovah, 2010: 76) menyebutkan theraband therapy 


\section{MEDIKORA Vol. XIV No. 1April 2015}

merupakan salah satu bentuk terapi latihan berupa karet yang berfungsi untuk pemulihan cedera dan membantu memperkuat fungsi kerja otot.

Theraband therapy mempunyai tingkat efektivitas yang tinggi dalam menangani pemulihan pasca cedera pergelangan tangan. Efektivitas terlihat dari kemampuan ROM pada pengamatan pretest ke posttest I, posttest I ke posttest 2, posttest 2 ke posttest 3 dan pretest ke posttest 3 . Tingkat efektivitas pada pengamatan posttest 3 yaitu pada pengamatan fleksi sebesar 95,08 \%, pada pengamatan ekstensi sebesar 92,19\%. Tingkat efektivitas pada pengamatan abduksi sebesar 90,67\% dan pada pengamatan adduksi sebesar $96 \%$. Hasil ini dapat diketahui bahwa theraband therapy sangat efektif digunakan dalam penanganan pasca cedera pergelangan tangan. Hasil uji one way anova juga menunjukkan adanya perbedaan yang signifikan antar pengamatan. Dilihat dari nilai rerata hasil pengamatan posttest 3 menunjukkan angka rerata terbesar. Hal ini dapat diartikan bahwa tingkat kesembuhan terbesar terjadi pada hasil posttest 3 .

Secara keseluruhan dapat disimpulkan bahwa theraband therapy yang mempunyai tingkat keberhasilan yang signifikan dalam menangani pemulihan pasca cedera pergelangan tangan Tim UKM Softball UNY. Hasil ini menunjukkan bahwa theraband therapy dapat dipilih dan digunakan sebagai salah satu jenis terapi untuk penanganan pasca cedera pergelangan tangan. Pengunaan theraband therapy untuk penanganan cedera pergelangan tangan dengan teknik dan dosis yang tepat mempunyai keberhasilan yang efektif dalam menyembuhkan cedera pergelangan tangan yang dialami oleh responden.

\section{KESIMPULAN}

Berdasarkan hasil analisis data dan pembahasan dapat disimpulkan bahwa Theraband therapy yang diberikan pada Tim UKM Softball UNY mempunyai tingkat keberhasilan yang signifikan dalam menangani pemulihan pasca cedera pergelangan tangan ( $p$ value $<0,05)$. Ditunjukkan dengan adanya peningkatan yang signifikan kemampuan ROM meliputi fleksi, ekstensi, abduksi dan adduksi pada pengamatan pretest ke posttest I, posttest I ke posttest 2, posttest 2 ke posttest 3 dan pretest ke posttest 3 . Tingkat efektivitas pada pengamatan posttest 3 yaitu pada pengamatan fleksi sebesar 95,08 \%, pada pengamatan ekstensi sebesar 92,19\%. Tingkat efektivitas pada pengamatan abduksi sebesar 90,67\% dan pada pengamatan adduksi sebesar $96 \%$.

\section{DAFTAR PUSTAKA}




\section{MEDIKORA Vol. XIV No. 1April 2015}

Ali Satia Graha dan Bambang Priyonoadi. (2009). Terapi Masase Frirage Penatalaksanaan Cedera pada Anggota Tubuh Bagian Atas. Yogyakarta: FIK UNY.

American geritrics society. (2001). "Exercise Prescription for Older Adults With Osteoarthritis Pain: Consensus Practice Recommendation”. JAGS; 49: 808-23

Arif Setiawan. (2011). Faktor Timbulnya Cedera Olahraga. Jurnal Media Ilmu Keolahragaan Indonesia., Volume 1., Edisi 1. Semarang: UNNES.

Basmajian, John V. (1980). Therapeuic Exercise. Baltimore: Williams dan Wilkins Company

C.K.Giam and K.C.Teh. (1992). Ilmu Kedokteran Olahraga (Hartono Satmoko, Terjemah) Jakarta: Penerbit: FIK UNY.

Dwi Hatmisari Ambarukmi, dkk. (2010). Masase Olahraga (Pendukung Prestasi dan Terapi Cedera Olahraga). Jakarta: Deputi Biddang Peningkatan Prestasi Olahraga Asdep Tenaga Keolahragaan.

G. La. Cava. (1995). Pengobatan dan Olahraga Bungan Rampai. Semarang: Dahara Prize

Hardianto Wibowo. (1995). Pencegahan dan Penatalaksanaan Cedera Olahraga. Jakarta: Penerbit Buku Kedokteran.

Havid Maimurahman dan Cemy Nur Fitri. (2012). Keefeektifan Range Of Motion (Rom) Terhadap Kekuatan Otot Ekstremitas Pada Pasien Stroke. Jurnal Profesi Kesehatan Islami, Vol 09.Surakarta: Akper Muhamadiyah Surakarta.

Lee, A., Wong, W., \& Wong, S. (2005). "Clinical Guidelines for Managing Lowerlimb osteoarthritis in Hongkong Primary care setting", Guidelines: 130.Tenaga Keolahragaan.

Novita Intan Arofa . (2010). Dasar-Dasar Fisioterapi pada Cedera Olahraga. Fakultas Ilmu Keolahragaan Universitas Negeri Yogyakarta.

Potter \& Perry. (2005). Buku Ajar Fundamental Keperawatan: Konsep, Proses, dan Praktik, Jakarta: EGC

Philip Page and Todd S. Ellenbecker. (2003). The Scientific and Clinical Application of Elastic Resistance. USA: Sheridan Books, Inc.

Riduwan, (2009). Dasar-dasar statistika. Bandung: Alfabeta.

Sadoso Sumosardjuno. (1990). Cedera Olahraga Di Arena. Jakarta: Pusat IlmuKeolahragaan. Koni Pusat. 
MEDIKORA Vol. XIV No. 1April 2015

Sugiyono. (2009). Metode Penelitian Administrasi. Bandung: Alfabeta.

Susan J. Garison. (2001). Dasar-Dasar Terapi dan Rehabilitasi Fisik. Jakarta: Hipokrates

Taylor, P.M dan taylor, D.K. (2002). Mencegah dan Mengatasi Cedera Olahraga. (Jamal Khalib, Terjemahan). Jakarta: RT. Grafindo Persada. Buku asli diterbitkan tahun 2002.

Yustinus Sukarmin. (2005). Cedera Olahraga Dalam Perspektif Teori Model Ekologi. Jurnal Media Ilmu Keolahragaan Indonesia., Volume 1., Edisi 1. Yogyakarta: UNY. 